The International Journal of Engineering and Science (IJES)

|| Volume || 6 || Issue || 6 || Pages || PP 50-61 || 2017 ||

ISSN (e): $2319-1813 \operatorname{ISSN}$ (p): $2319-1805$

THE IJES

\title{
The Effect of Firm size and Diversification on Capital Structure and FirmValue (Study in Manufacturing Sector in Indonesia Stock Exchange)
}

\author{
Hasby Hamyat ${ }^{1}$, Buyung Sarita ${ }^{2}$, Hasbudin ${ }^{3}$, Sujono ${ }^{4}$ \\ ${ }^{1}$ Doctoral Program of Management Science, Halu Oleo University Kendari \\ Southeast Sulawesi, Indonesia \\ ${ }^{2,3,4}$ Faculty of Economics and Business. Halu Oleo University, Southeast Sulawesi, Indonesia
}

\begin{abstract}
This study aims to examine and analyze whether firm size, diversification, and capital structure to the firm value. The design of this study was to raise the theory of Modigliani and Miller and fundamental theories in financial management that discuss some of the functional relationship fundamental variables that determine the capital structure and corporate value. The locations of this study are in the Stock Exchange Indonesia at Jalan Sudirman Jakarta and Makassar Capital Market Information Center. The data collection of this study conducted at the beginning of April to the end of July 2015. The study population was 150 companies listed on the Indonesia Stock Exchange until the end of 2014. Sampling is purposive sampling with criteria for manufacturing companies listed in Indonesia Stock Exchange during the period of observation that is in 20062014, have complete data, have been audited by the auditor's opinion unqualified, published financial statements, and have positive equity, so that the total sample of 17 companies. The method used in this research is the analysis of structural equation modeling. The results showed no effect of capital structure on Firm's value. Diversification and Firm Size effect on firm value. Diversification has effect on capital structure. Firm size has no effect on the structure. No mediation effect of capital structure on relationship between diversification and Firm value. But there is mediation effect of capital structure to influence firm size on firm value.
\end{abstract}

Keywords: Firm size, Diversification, Capital Structure, Firm Value.

Date of Submission: 03 June 2017

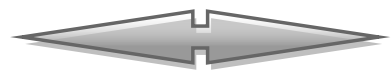

Date of Accepted: 22 June 2017

\section{INTRODUCTION}

Companies in the manufacturing industry still increase its size by expanding, although Bank Indonesia and the government's policy of maintaining economic growth by raising interest rates and tightening liquidity. Investors will invest up to $\mathrm{Rp} 96.5$ trillion for the automotive sector, cement, and food and beverage processing. Of these investments, as much as US \$ 2 billion or Rp 24 trillion invested in the automotive sector, cement Rp 32.5 trillion, and food beverage $\mathrm{Rp} 40$ trillion. Interestingly, foreign investors are also increasingly keen to invest in the manufacturing sector and new investments more and more. Domestic investment (DI), the portion of the processing sector is relatively stable from $40.3 \%$ to $40 \%$. However, in terms of value increased significantly from Rp 24.4 trillion to $\mathrm{Rp} 51.2$ trillion. In general, the realization of investment from 2010 to 2013 continued to grow, namely a row of $\mathrm{Rp} 208.5$ trillion to $\mathrm{Rp} 251.3$ trillion to $\mathrm{Rp} 313.2$ trillion and $\mathrm{Rp} 398.6$ trillion, totaling Rp 1171.6 trillion (Kemenperindag.17 October 2016)

This study aims to examine and analyze whether the size of the company, diversification and capital structure to the company's value. And test and analyze whether the size of the company, diversification of the company's value that is mediated by the capital structure

Large-sized companies have many advantages compared to small-sized companies. Large companies able to produce products with a low price per unit for production in economies scale. According Eljelly in Akoto, Vitor and Angmor (2013) big companies can buy raw materials in bulk so that large companies get discounts (quantity discount) from the supplier. Large companies can also get soft credit terms from suppliers than smaller companies. Large companies are also able to collect receivables faster than small companies. Therefore, the larger size of company, the higher its profitability. Large-sized manufacturing company is certainly different from the small and medium sized if the terms of the internal conflict. According to Jensen and Meckling in Shubitadan alsawalhah Maroof (2012), the company that the greater will be potentially exposed agencyproblems as a result of the separation between the functions of decision-makers and risk insurer (riskbeating). 
The findings about the effect of firm size on the capital structure show their support for the theory of trade-off. Companies Size according to Bevan and Danbolt (2000), Moh'd et al. (1998), Chan et al. (1998), Booth et al. (2001), Bunkanwanicha et al. (2003), Sudarma (2004), Zou and Xiao (2006), Pandey (2001), Gaud et al. (2006), Li et al. (2003), a positive effect on the capital structure. While the negative effects found in the study Titman and Wessels (1988). Finding a positive effect on the capital structure of firm size showed their support for the theory of trade-offs. It means that the benefits of the use of debt are greater than the cost of the use of debt to big companies. The condition occurs because large companies have better access and higher bargaining power of small companies so that the cost of debt is smaller. This has an impact that large companies use more debt. Instead negative effect on the capital structure of firm size showed their support for the pecking order theory. Large companies have a better ability to convey information prospect projects to be executed that responded positively by the market, thus increasing the share price and lowers the use of debt.

The capital structure of the company's manufacturing industry experienced Generally Increase overseas. Debt experienced an increase of manufacturing industry. As for Indonesia's foreign debt at the end of the first quarter of 2016 amounted USD316,0 billion, growing 5.7\% (yoy). Generally, Indonesia's foreign debt comes from the manufacturing sector and the power sector, and gas and water. So the conditions of long-term foreign debt recorded increases, while the short-term foreign debt decreased. The ratio of foreign debt to Gross Domestic Product (GDP) the end of the first quarter of 2016 Stood at $36.5 \%$, a slight increase of is from $36.0 \%$ at the end of the fourth quarter of 2015 the foreign debt owed by Indonesia is dominated by long-term foreign debt by the end of the first quarter of 2016 Reached USD277,9 billion. (Kunthi Fahmar SandySelasa, May 17, 2016 SindoNews.Com).

Companies in the manufacturing industry still Increase of its size by expanding, Although Bank Indonesia and the government's policy of maintaining economic growth by raising interest rates and tightening liquidity. Investors will invest up to Rp 96.5 trillion for the automotive sector, cement, and food and beverage processing. From reviews these investments, as much as US \$ 2 billion or Rp 24 trillion invested in the automotive sector, cement Rp 32.5 trillion, and food and beverage processed Rp 40 trillion. Interestingly, foreign investors are keen to invest Increasingly Also in the manufacturing sector and new investments more and more. Domestic investment (DI), the portion of the processing sector is acres are relatively stable from $40.3 \%$ to $40 \%$. However, in terms of value increased significantly, from $\mathrm{Rp} 24.4$ trillion to $\mathrm{Rp} 51.2$ trillion. In general, realization of investment from 2010 to 2013 continued to grow items, namely a row of Rp 208.5 trillion to Rp 251.3 trillion, Rp 313.2 trillion and $\mathrm{Rp} 398.6$ trillion, totaling Rp 1171.6 trillion. (Kemenperindag.17 October 2016).

The enterprise value of the manufacturing industry Increased reflected on the prospects of the capital market in Indonesia. Investment flowing to the sector of automotive components and assembling cars this year, with the increasing number of models assembled and the growing sales of cars. Based BKPM of foreign corporate investment (FDI) in the manufacturing sector last year reached US \$15.7 billion, investment in the automotive sector Reached US \$ 3.6 billion. While local companies manufacturing investment (DI) last year roomates Reached Rp 51 trillion, Rp 2 trillion into sectors of the automotive manufacturing industry stock investment. IS ALSO growth driven by consumption patterns According to Smith (2010), proved that simultaneous significant effect of firm size companies. Size rate against companies deemed capable of affecting the value of the company will get a refund that benefit from the company.

Diversification in industrial environmental organization has affect business performance. Many studies concerning diversification like Lang and Stulz (1994), Berger and Ofek (1995), and Provides strong evidence that the diversity of business give more value to the company when Compared to specialized businesses. The effect of diversification will improve Reviews their business performance by developing products and markets. Diversification is a growth strategy that improves business performance, such as sales growth, market share growth. Diversification is Generally Carried out by the investor to retain customers.

Diversification is very influential on the capital structure. Companies can reduce the risk by doing activities diversification so as to increase the capacity of the company's debts. According to the transaction cost theory, this type of diversification adopted by a company depends on the nature of the resources that led the company to diversify. The types of assets used by an enterprise affect the financial decisions it is possible to establish a relationship between capital structure and strategy of diversifying the company (Oviatt, 1984). Qureshi, Akhtar and Imdadullah (2012).

From an empirical analysis of this study support the transaction cost theory and the theory coinsurance for a company diversified its product and geographic diversification has consequences amount of debt that is greater than compared with companies non-diversified.

The problem of this research is:

1. What is the size of the company have a significant effect on the capital structure?.

2. Do diversified significant effect on the capital structure?.

3. Is the capital structure significantly influences the value of the company? 
4. Is the company size significantly influences the value of a company that is mediated by the capital structure?

5. Do diversified significant effect on the value of the company that is mediated by the capital structure?

Theory of Value Company

\section{LITERATURE REVIEW}

The purpose of financial management is to maximize the value of the company. If the company goes smoothly, it will increase the company's stock value, while the values of corporate debt (bonds) are not affected at all (Mas'ud, 2008). For this reason, the purpose of financial management is Often in the form of company stock value maximization, or simply the maximization of share price (Weston and Copeland, 1997) .some proxy for measuring the value of the company.

Positioned as a professional manager or manager's commissioner, an alternative one used in measuring the value of the company is to use Tobin's Q. This ratio was developed by Professor James Tobin (1967). This ratio is a valuable concept because it shows the current estimate of the financial markets on the value of the return on every dollar of incremental investment. If the q-ratio above one indicates that the investment in assets to generate profits that provide higher value than investment expenditure, this will stimulate new investment. If the ratio is below one-q, investment in assets is not attractive.

\section{Capital Structure Theory}

Capital structure by Brigham and Joel (2004: 486) as: "a combination of equity and debt". Furthermore, Sartono (1997: 295) stated capital structure is in proportion to the number of short-term debt that is permanent, longterm debt, preference shares and ordinary shares ". Understanding the structure of capital raised Sartono (1997) is a broader sense than the other notions, because not only include long-term debt, but also short-term debt that is permanently used by the company.

\section{Modigliani Miller (MM)}

Until 1958 the capital structure theory yet bold statement about investor behavior that can be tested statistically (Brigham, Gapenski, 1996: 365), until Franco Modigliani and Merton Miller (MM) published a paper in 1958. The paper resulted in an Thanks to a capital structure issues and has spawned various theories of capital structure.

M odigliani-Miller develops models of capital structure and capital structure without tax with tax models. Value company with tax, is higher than the value of the company without the tax. Obtained difference through tax savings, the interest can be used to reduce taxes. The tax savings can be calculated with the formula Tax Savings $=V_{-} L_{-} V_{-} U=$ t.D. Miller then develop a models of capital structure by inserting personal. Consideration taxes that shareholders and debt holders has to pay tax if they receive dividends or interest. After entering the personal tax ( $t$ ) the formula for calculating the value of a company that has debt is as follows: $V L=V_{U}+\left\{1-\frac{(1-T)(1-t)}{(1-t d)}\right\}$. Based on the previous equation, the goal is not only to minimize corporate taxes, but to minimize the total of tax (corporation tax, tax for the shareholders and for the tax debt holders). Equation 2.9 has several implications. If $(1-\mathrm{td})=(1-\mathrm{T})(1-\mathrm{t})$, then the equation 2.9 becomes: V_L $=\mathrm{V} \_\mathrm{U}+(1-1)$ $\mathrm{B}=\mathrm{V}$ _U. In other words, in these conditions the value of the company with debt equal to the value of the company without debt. There are no tax savings on interest on the debt. In this situation, where $t=t d, 2: 10$ equations can be written as follows: $V L=V U+T \cdot D$

\section{Packing Order Theory}

Pecking order theory does not set capital targets. Structure theory only describes the sequences of funding. According to the pecking order theory, financial managers do not take into account the level of debt that optimal. Needs funds is determined by investment needs. If there is an investment opportunity, the company will seek funds to finance Reviews These investments. First of all, the company will use internal funds. If internal funding sources are not sufficient, then the company issuing debt and if the funding requirements has not been enough, the company issued the shares. In addition to the investment needs, another consideration is the payment of dividends. The dividend will lead to reduced cash funds. If cash is reduced, then the company will issue new securities.

\section{Signaling theory}

Theory signaling by Ross (1977) developed a model of the use of debt as a signal delivered by the manager to the market. If the manager has confidence the company's has good prospects. Then the manager wants to communicate it to the investor. One of the simplest ways is to say directly "Our Company has good prospects". Of course, investors will not take anything for granted. Managers can use more debt, as a credible signal. 


\section{Theory of Firm Size Firm Size}

Company size is measured as the volume of sales of a company. Proxies are used to calculate the size is the log of net sales. Many writers (Gaudi, et al. (2003), Masnoon \& Anwar (2012), Rajan and Zingales (1995) in a research study they have found a negative relationship between firm size and leverage as there is transparency about the big companies that reduce undervaluation problem of new equity and encourages companies to equity finance through them. the size companies: measured by the natural logarithm of total assets (Onaolapo and Kajola (2010) and Rajan and Zingales (1995).

\section{Verified theory}

Diversification is a strategy of diversification of products and markets to improve business performance. Miller (1983), that the diversification of markets and products to generate profits. Diversification is done in the form of major integration expertise, and market potential, to reduce the cost of capital, an increase of sales. Diversification of products and markets are very flexible to the sales forecast. Thus, diversification is a step in the diversification of business efficiency to improve performance. Diversification helps business development (business development) to develop old and new products in the market of old and new. Four combinations of products and markets that generate four options in the diversified business strategy items, namely:

1. Market penetration by using the existing products in the market today (Market Penetration: Existing products in the market).

2. Development of new products in the market now (Product Development: Existing market new products).

3. Development of the market with new products now on the market (Market Development: Existing products in New market)

4. Diversification into new markets with new products (Diversification: New market in new products)

\section{METHOD}

The design of this study was to conceptualize the relationship structure variables of a study used as guidelines for research that leads to the goal of this research (Aaker, 1980). Draft test research and causality hypothesis is explanatory research design. The research raises the theory of Modigliani and Miller and fundamental theories in financial management that discusses some of the fundamental variables functional relationship Determine that capital structure and corporate value. The research location is on the Indonesia Stock Exchange on Sudirman Street Jakarta and Makassar Capital Market Information Center. The collection of data of this study conducted at the beginning of April to the end of July 2015. The study population was the whole company listed on the Indonesia Stock Exchange until the end of the year 2014.Metode used in this research is the method of Partial Least Square (PLS) analysis, the which is a multiple regression equation groove connected simultaneously, and for measurements with the help of software Smart PLS analysis is part of the analysis of structural equation modeling (SEM). The study population was 150 manufacturing companies. This study has a population of all manufacturing companies listed in Indonesia Stock Exchange until the study was started, ie as of 1 May 2015. According to information from the Indonesian Stock Exchange, sectors classified as a manufacturing company is a company engaged in a variety of industries. Issuers are becoming a sample of 17 of the 150 listed companies because it meets all the criteria of the sample by purposive sampling technique. The sample in this study were taken by purposive sampling method of sampling based on criteria that companies listed in Indonesia Stock Exchange during the observation period the year 2006-2014, have complete data during the observation period for the factors studied, have been audited by opinion unqualified auditor, issuing financial statements and notes to the financial statements for 2006-2014, respectively, and have positive equity. Then the number of companies that meet the criteria adalah17 company, look at Tabel.1

Table 1. Sample Data Companies Manufacturing Sector

\begin{tabular}{|c|l|c|}
\hline No. & \multicolumn{1}{|c|}{ Name of Manufacture } & Type of Manufacture \\
\hline 1 & Delta Djakarta Tbk (DLTA) & Food \& Drink \\
\hline 2 & Mayora Indah Tbk (MYOR) & Food \& Drink \\
\hline 3 & Gudang Garam Tbk. (GGRM) & cigarette \\
\hline 4 & H.M. Sampoerna Tbk. (HMSP) & pharmacy \\
\hline 5 & Merck Tbk (MERK) & pharmacy \\
\hline 6 & Taisho Pharmaceutical Indonesia Tbk. (SQBI) & pharmacy \\
\hline 7 & Tempo Scan Pacific Tbk. (TSPC) & Cosmetics \\
\hline 8 & Mandom Indonesia Tbk. (TCID) & Cosmetics \\
\hline 9 & Unilever Indonesia Tbk. (UNVR) & Cement \\
\hline 10 & Semen Gresik (Persero) Tbk. (SMGR) & Metals \& Ships \\
\hline 11 & Lion Metal Works Tbk. (LION) & Metals \& Ships \\
\hline 12 & Lionmesh Prima Tbk. (LMSH) & Plastics and Packaging \\
\hline 13 & Champion Pacific Indonesia Tbk. (IGAR) & Automotive and Components \\
\hline 14 & Astra International Tbk. (ASII) & Automotive and Components \\
\hline 15 & Astra Otoparts Tbk. (AUTO) & Automotive and Components \\
\hline 16 & Indo Kordsa Tbk. (BRAM) & Automotive and Components \\
\hline 17 & Goodyear Indonesia Tbk. (GDYR) & \\
\hline
\end{tabular}

Source: Stock Exchange Indonesia (2014) 
2. Hypothesis

The hypothesis according to research model can be constructed as in Figure 1.

Company size is an important factor in deciding capital structure, this finding is supported by Chen and Strange (2006). Elsas and Florysiak (2008). Song (2005), Bevan \& Danbolt (2002), Homaifer et al. (1994).

Based on the explanation the hypothesis drawn were:

H1 = Firm Size has positive and significant effect on Capital Stucture

Diversification determine capital structure, this finding is supported by sighn et al (2003), Hitt et al, (2006), Chen et al., (1997), Singh et al (2003), and La Rocca, et al (2009).

Based on the explanation the hypothesis drawn were:

H2 = Diversified has significant and positive effect on Capital Structure

The size of the company determines the value of the company; this finding is supported by Bambang (2001), Smith (2010), Rachmawati, et al (2007), Siallagan and Mas'ud (2006), Michell Suharli (2006).

Based on the explanation the hypothesis drawn were:

H3 = Firm Size has positive and significat effect on Firm Value

Values Businesses in mediation Capital Structure

Diversification affect the value of the company, is supported by the findings by Berger and Ofek (1995: 40), Jensen (1986: 2), Berger and Ofek (1995: 49).

Based on the explanation the hypothesis drawn was:

Diversified Capital H4 = significant positive effect on companies that in the mediation Value Structure

The capital structure determines the value of the company; this finding is supported by Wippern (1966), Holz (2002), Ross (1997).

Based on the explanation the hypothesis drawn was:

H5 = significant positive effect on Values Company's Capital Structure

Based on this hypothesis, the research model can be constructed as in Figure 1

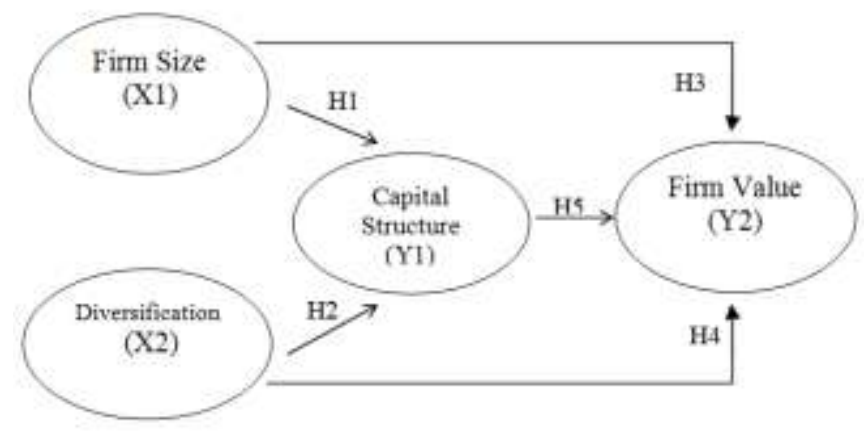

Based on the conceptual framework in the model path analysis above, it can be formed of functional equations in the model with the reduced form as follows:

$$
\begin{aligned}
& Y_{1}=f\left(X_{1}, X_{2}\right) \\
& Y_{2}=f\left(X_{1}, X_{2}, Y_{1}\right)
\end{aligned}
$$

Then organized into the following equation

$$
\begin{aligned}
& Y_{1}=\alpha_{0}+\alpha_{1} X_{1}+\alpha_{2} X_{2}+\varepsilon_{1} \\
& Y_{2}=\alpha_{0}+\beta_{1} X_{1}+\beta_{2} X_{2}+\beta_{3} Y_{1}+\varepsilon_{2}
\end{aligned}
$$

The indicators and measurement of latent variables, namely:

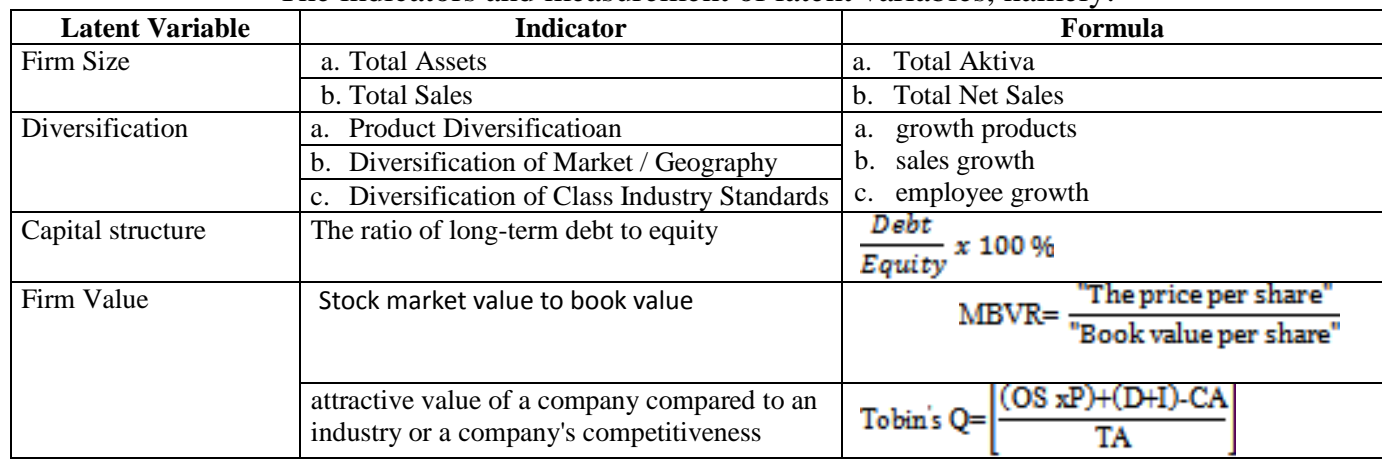


Based on the above functional model (1 and 1), then the model equations linear function or form of the regression equation can be written can be continued in the form of the smallest equation reduce form. To estimate the above equation, it cannot be done with OLS (Ordinary Least Square) prior to the identification of coefficients by moving all the endogenous variables to the left and to the right of the exogenous variables, as follows:

$$
\begin{gathered}
{\left[\begin{array}{cr}
1 & 0 \\
-\beta_{4} & 1
\end{array}\right]\left[\begin{array}{l}
Y 1 \\
Y 2
\end{array}\right]=\left[\begin{array}{c}
\alpha_{0}+\alpha_{1} \mathrm{X}_{1}+\alpha_{2} \mathrm{X}_{2}+\varepsilon_{1} \\
\beta_{0}+\beta_{1} \mathrm{X}_{1}+\beta_{2} \mathrm{X}_{2}+\beta_{3} \mathrm{X}_{3}+\varepsilon_{2}
\end{array}\right]} \\
{\left[\begin{array}{l}
Y 1 \\
Y 2
\end{array}\right]=\frac{1}{1}\left[\begin{array}{cr}
1 & 0 \\
-\beta_{4} & 1
\end{array}\right]^{T}\left[\begin{array}{c}
\alpha_{0}+\alpha_{1} \mathrm{X}_{1}+\alpha_{2} \mathrm{X}_{2}+\varepsilon_{1} \\
\beta_{0}+\beta_{1} \mathrm{X}_{1}+\beta_{2} \mathrm{X}_{2}+\beta_{3} \mathrm{X}_{3}+\varepsilon_{2}
\end{array}\right]}
\end{gathered}
$$

Each variable $\mathrm{x} \wedge \mathrm{i}$ associated with the function $\left\{B_{1, \ldots,}^{\mathrm{i}}, B_{r_{i}}^{\mathrm{i}}\right\}$ called $\mathrm{B}$-splines or splines basis in the regression equation, namely $s^{i}(x)=\sum_{k=1}^{\gamma_{i}} \theta_{k}^{i} B_{k}^{i}(x), s^{i}$ spline limited to the range $\left[x_{-}^{i}, x_{+}^{i}\right]$ dari $x^{i}$, polynomials which are formed at the level of $\mathrm{d}^{\wedge} \mathrm{i}$ associated with $\mathrm{K}^{\wedge} \mathrm{i}$ points at the interval $] x_{-}^{\mathrm{i}} x_{+}^{\mathrm{i}}[$ which later became $0 \leq B_{k}^{i}(x) \leq 1$ dan $\sum_{k=1}^{\gamma_{i}} B_{k}^{i}(x)=1$.

Basic of PLS Equation is $t=h(X, \theta)=\sum_{i=1}^{p} \sum_{k=1}^{\gamma_{i}} \theta_{k}^{i} B_{k}^{i}\left(x^{i}\right)=\sum_{i=1}^{p} h_{i}\left(x^{i}\right)$. Each component PLS represent the number of spline functions and coordinate curve $\left\{\left(x^{i}, h_{i}\left(x^{i}\right)\right)\right\}_{i=1}^{i}, p$ yang usually interpreted as the influence of different variables on the latent variable $t$. Measurable dimensions of $\mathrm{p}$ on the model $r=\sum_{1}^{p} r^{i}$. PLS algorithm is based on a matrix equation $X$ with columns $\mathbf{B}=\left[\mathbf{B}^{1}|\ldots| \mathbf{B}^{\mathrm{P}}\right]$. By replacing $\mathrm{X}$ by :

$$
\begin{aligned}
& \left(B_{1}^{1}\left(x^{1}\right), \ldots, B_{\gamma_{1}}^{1}\left(x^{1}\right), \ldots, B_{1}^{p}\left(x^{p}\right), \ldots, B_{v_{v}^{p}}^{p}\left(x^{p}\right)\right) \text { and combined into equation } \\
& \hat{y}^{j}(M)=\sum_{i=1}^{p} \sum_{k=1}^{r_{i}} \beta_{k}^{j}(M) B_{k}^{i}\left(x^{i}\right)=\sum_{i=1}^{p} s_{M}^{j, i}\left(x^{i}\right), \quad j=1_{s \ldots s} q
\end{aligned}
$$

Figure 2. Diagram Equation PLS which later became

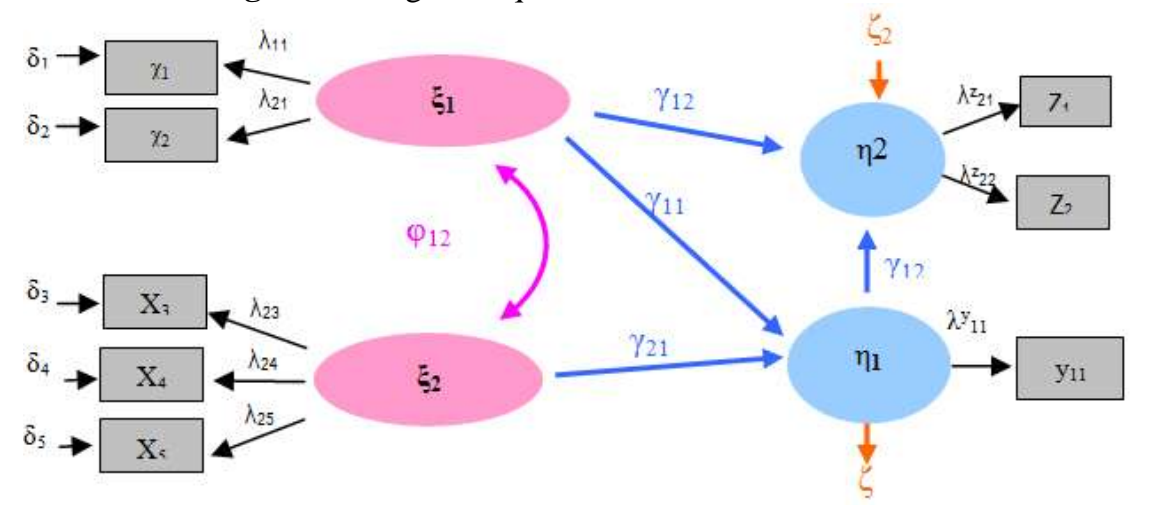

Given the model set out in this study is the path to the simultaneous equations, and the data obtained in the form of data ratio, then the data analysis methods deemed most appropriate for analyzing such data is path analysis with technical structure model equations or Structural Equation Model (SEM) using PLS (Partial least Square) in Figure estimation of the parameters in the PLS is least square methods that includes three terms (Solimun 2008; priest, 2008):

Weight estimate used to calculate the latent variable data.

Path estimate that connects between the latent variables and the estimation of loading between the latent variables with the indicator.

Means and location parameters (value of the constant regression, intercept) to indicators and latent variables

As a first step iterative approximation algorithm is calculating the outside estimate of latent variables by adding the main indicators in each group the indicators with equal weights for each iteration.Weight scaled to get unit variance of latent variable score to $\mathrm{N}$ scaled cases in the sample. By using the scores for each latent variable that has been estimated to be done inside approximation estimate the latent variables.

Based on estimates of the latent variable approximation inside, obtained a set of new weighting of approximation outside. If the score approximation inside made permanent (fixed), then do a simple regression or regression depending on whether the indicator is variable latent formative or reflective. Therefore $\xi_{-} 1, \eta \_1$, and $\eta \_2$ is reflexive to the direction of causality as if from latent variables to indicators, each indicator within each group of indicators of latent variables individually regressed to estimate the latent variables (score approximation inside). In the case of a formative model $\xi_{-} 2$ shaped by the direction of causality as if from the 
indicator to the latent variables, and then do regression to estimate $\xi_{-} 2$ against the indicator. Simple regression coefficient and multiple regressions were then used as the new weighting for the approximation outside any latent variables.

By explaining boosting as functional gradient can be described by the equation functions as follows: $\left\{y \_i, x \_i\right\}$ _ $(\mathrm{i}=1)^{\wedge} \mathrm{n}$, where $\mathrm{y} \in \mathrm{R}$ continuously against the regression equation, predictor is $" \mathrm{X}^{\prime \prime}=\left(\mathrm{x} \wedge 1, \ldots, \mathrm{x}^{\wedge} \mathrm{p}\right) \in \mathrm{R}^{\wedge}$

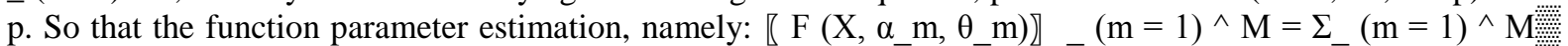
$\llbracket \alpha \_\mathrm{m} \mathrm{h}\left(\mathrm{X}, \theta \_\mathrm{m} \rrbracket\right)(1)$, wherein $\theta \_\mathrm{m}$ is the infinitive function parameters, $\alpha \_\mathrm{m}$ is a weighted coefficient and parametric function $\mathrm{h}(\cdot)$ is the basis for accommodating nonlinearitas functions and multiple interactions. Had expected the equation that produces a more efficient combination of the coefficients $\left\{\alpha_{-} \mathrm{m}\right\}_{-}(\mathrm{m}=1)^{\wedge} \mathrm{M}$ is considered crucial.

Goodness of fit testing are applied to both outer and inner models models.

Outer models, when the indicator bersfat reflexive, it is necessary to evaluate the calibration of instruments, namely the validation and reliability of the instrument:

\section{Convergen validity}

The correlation between the value of the latent variable indicator reflective of 0.5 to 0.6 is considered fairly in the number of indicators per latent variable is not large, ranging from 3 to 7 indicators.

\section{Discriminant validity}

Reflective indicator measurement based on cross loading with latent variables. When the value of cross loading on the latent variables in question compared to the largest cross loading on the other latent variables then be valid. The other method by comparing the square root of average variance extracted (AVE) any correlation between the latent variables with other latent variables in the model, if AVE latent variables is greater than the correlation with all other latent variables then said to have a good discriminant validity. Recommended value measurement should be greater than 0.5 (Solimun, 2008: 79).

\section{Composite reliability (pc)}

Groups of variables that measure a variable has a composite reliability was good if it has a composite reliability $\geq 0.7$, although not an absolute standard (Solimun, 2008, 79). ,

\section{Inner goodnes of Fit Testing Model}

Goodness of Fit Model for inner models is measured by R-square of latent dependent with the same interpretation with regersi: Q-square predictive relevance for the structural model, measure how well the observed values generated by the model and parameter estimation. Q-Square value> 0 indicates the model has predictive relevance; otherwise if the value of the Q-Square $\leq 0$ indicates the model lacks predictive relevance.

\section{Validity test}

Validity test is done to ensure that each question is classified in any of the variables have been set (Malhotra, 1999). The questionnaire has been prepared, tested by asking a question to a group of respondents with the aim to determine the extent of the measuring instrument has validity and reliability. The instruments are valid and reliable are the main requirements to obtain valid research results and riliabel (Sugiyono, 2002). The validity of a scale of measurement can be defined "the extent of the difference between the scores from the observation (observed scale score) shows the stark contrast between the object / respondent on the characteristic being measured and not for their systematic or random error". Valid or not an item can be determined by comparing the product moment correlation index with a value probabilittasnya (Arikunto, 2002), if the items are not significantly correlated at significant level 5persen, then the instrument disqualified. To test the validity, then used the Pearson Product Moment, where the instrument is said to be valid when the value of the correlation coefficient $(r)>r$ table.

\section{Reliability Test}

Reliability testing instrument in this study using Cronbach alpha coefficient formula by using SPSS package, whereby if a larger alpha value of 0.6 indicates the instrument reliable (Singarimbun, Masri., And Sofian, Effendi.1989)

Reliability could also be based on criteria according to Ferdinand (2006) which states that the reliability of an instrument can be accepted or not is by looking at the number of grains / categories used. If the amount of grain used as much as 5 item, then that item is said to be reliable if the standardized item alpha greater than or equal to 0.20 . When the amount of grain equal to 10 , then the standardized alpha coefficient should be greater than or equal to 0.33 . 


\section{RESULT}

In this research will be testing the validity and reliability on each latent variable is the variable environment, behavior, health care, and tax ratio by using statistical software SmartPLS. The size of individual reflexive considered valid if it has a value of loading $(\lambda)$ with latent variables to be measured $\geq 0.5$, if one indicator has a loading value $<0.5$, the indicator should be discarded (dropped) because it would indicate that the indicators are not good enough to measure latent variables appropriately. Here are the results of structural equation path diagram output in the PLS using SmartPLS software.

Based on the indications in Figure 3 shows that there are four indicator variable with a value of loading $(K)<0.5$, namely on the indicator variables X1, X2, X3, Y1 and Y2. Here are the results output to two, the path diagram on PLS structural equation by using software SmartPLS. Eleven indicators on the quality of service that must be aborted due to invalid in forming latent variables. Four indicators on compliance invite aborted, and then be retested

Figure 3 Model Test Early

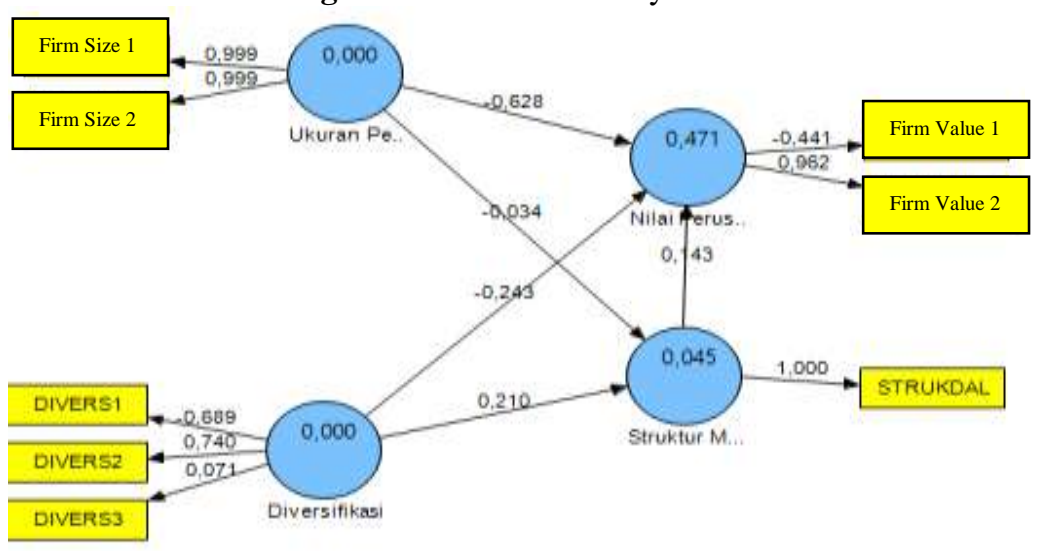

Based on Figure 5.2.loading factor whose value is below 0.60 or negative invalid and must be disposed of models. The following indicators have loading under 0.60 or negative, namely Divers3 0.071387 , and Nilaiper1 $-0,441423$ seperti visible on the outer loading test results in table 5.3 as follows:

Tabel 2.Uji Outer Loadings

\begin{tabular}{|l|c|c|c|}
\hline & Diversification & Firm Value & Firm Size \\
\hline Divers1 & $-0,688898$ & & \\
\hline Divers2 & 0,739642 & & \\
\hline Divers3 & 0,071387 & & \\
\hline Firm Value1 & & $-0,441423$ & \\
\hline Firm Value2 & & 0,961686 & \\
\hline Firm Size1 & & & 0,999085 \\
\hline Firm Size2 & & & 0,999047 \\
\hline
\end{tabular}

\section{Source: Processed Data SmartPLS}

Whereas the outer test in Table 5.3 shows two indicators of latent variables that should be eliminated, because it shows the loading under 0.6. For further last testing. In the image Once dropped in the run again and results are as follows:

Gambar 4. Model Uji Akhir

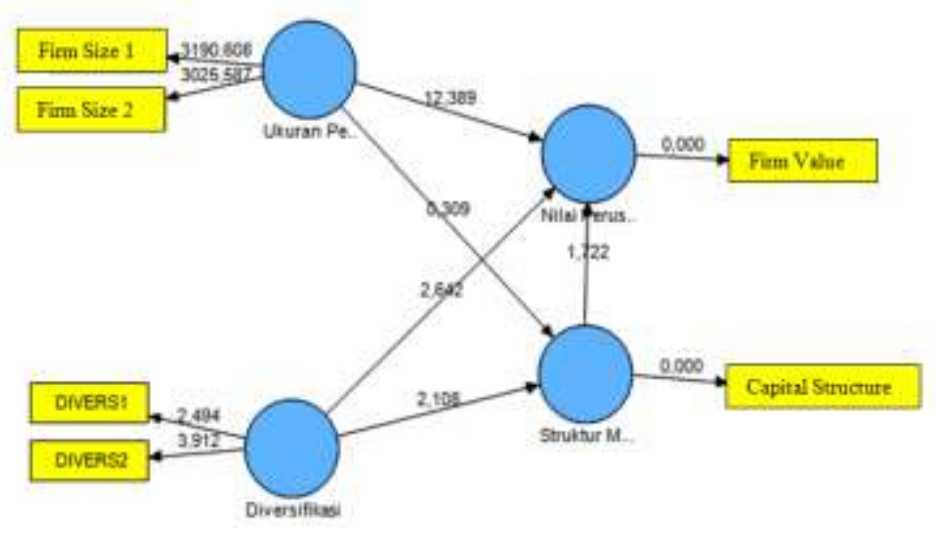


Based on the data running process stage after dropping outer indicator which does not meet the standards, then the next show that all loading factor are valid because above 0.60 and still remains one indicator of the indicator is made formative. Test the validity of the views of three things: the first value Convergent Validty>0.60 value loading factor should be above 0.60 has been tested at the beginning, two values Average Variance Extracted $(A V E)>0.5$ seen from the AVE in Table 3 shows all the variables has more validity AVE high because values above 0:50.

Table 3. Validity testing

\begin{tabular}{|l|c|c|c|c|}
\hline & AVE & $\begin{array}{c}\text { Composite } \\
\text { Reliability }\end{array}$ & R Square & Cronbachs Alpha \\
\hline Diversification & 0,51093 & 0,000622 & & $-0,044727$ \\
\hline Firm Value & 1 & 1 & 0,476226 & 1 \\
\hline Capital Structure & 1 & 1 & 0,045042 & 1 \\
\hline Firm Size & 0,998133 & 0,999066 & & 0,998129 \\
\hline
\end{tabular}

Source: Processed Data SmartPLS

Results of testing the indicators in Table 3 is comparing between the roots of the correlation between variables AVE. In Table 3 menunjukkandiscrimant validity diagonal AVE output that value and the other value is correlated between variables. When viewed from the output, then all the diagonal value is higher than the correlation between variables, and thus all models meet discrimant good validity.

\section{Reliability Test}

Reliability test using compositerealibility> 0.70 which is the condition good reliability. When viewed from the composite output realibility in Table 4 also can be seen from the value of Cronbach Alpha> 0.70 are considered good, walaupu thus the value of the company is not reliable, but the source of research data is secondary data, then it is a characteristic of data.

Table 4 Reliability Test

\begin{tabular}{|l|c|c|c|c|}
\hline & R Square & $\begin{array}{c}\text { Cronbachs } \\
\text { Alpha }\end{array}$ & $\begin{array}{c}\text { Composite } \\
\text { Reliability }\end{array}$ & Description \\
\cline { 2 - 5 } & & $-0,044727$ & 0,000622 & Not Reliable \\
\hline Diversification & 0,476226 & 1 & 1 & Reliable \\
\hline Capital Structure & 0,045042 & 1 & 1 & Reliable \\
\hline Firm Size & & 0,998129 & 0,999066 & Reliable \\
\hline
\end{tabular}

\section{Source: Processed Data SmartPLS}

\section{Significance of Model}

Significance test models using resampling techniques boostraping with 1000 and the results can be seen in Table 5.di below and in the model image shows the value $t$ statistic of relationship between variables that will be compared with the value $t$ table

Table 5.Path Coefficient

\begin{tabular}{|c|c|c|c|c|c|c|}
\hline \multicolumn{2}{|c|}{ Variable Eksogen } & \multirow{2}{*}{$\begin{array}{l}\text { Variable } \\
\text { Endogen }\end{array}$} & \multirow{2}{*}{$\begin{array}{c}\text { Sample } \\
\text { Mean (M) }\end{array}$} & \multirow{2}{*}{$\begin{array}{l}\text { Standard } \\
\text { Error }\end{array}$} & \multirow[t]{2}{*}{ T Statistics } & Significance \\
\hline & & & & & & \\
\hline & & Volue & 06204 & 00512 & 123801 & Fffor \\
\hline Firm Value & $->$ & & $-0,2167$ & 0.0821 & 2,6422 & Effect \\
\hline Capital Structure & $->$ & & 0,1577 & 0,0978 & 1,7217 & No Effect \\
\hline Firm Size & $->$ & Capital & $-0,0467$ & 0,1105 & 0,3088 & No Effect \\
\hline Diversification & $->$ & Structure & 0,2224 & 0,0998 & 2,1075 & Effect \\
\hline
\end{tabular}

\section{Source: Processed Data SmartPLS}

a. Based on Table 6 shows some indirect coefficients between exogenous variable to the value of the company through a capital structure as follows:

b. a. Not strong indirect effect on corporate value through a diversified capital structure with 0.048menunjukkan coefficient value of the coefficient is negative and significant, meaning capital structure did not mediate the relationship between diversification and firm value.

c. b. There is an indirect effect of firm size on corporate value through its capital structure with a coefficient of 0.029 , indicating the value of the coefficient is positive and significant, meaning capital structure mediates the relationship between firm size and firm value. 
Table 6. Indirect Effect

\begin{tabular}{|l|c|c|c|}
\hline \multirow{2}{*}{ Variable } & \multicolumn{2}{|c|}{ Total Effect } & \multirow{2}{*}{ Indirect Effect } \\
\cline { 2 - 3 } & Capital Structure & Firm Value & \\
\hline Firm Size & $-0,0467$ & $-0,6294$ & 0,029 \\
\hline Diversification & 0,2224 & $-0,2167$ & $-0,048$ \\
\hline
\end{tabular}

Source: Processed Data SmartPLS

\section{CONCLUSION}

Based on data analysis and discussion of the research results can be concluded as follows:

a. Capital structure does not affect the value of the company for additional loan capital only affect the development of the business units, but still in the early stages of development of new investments and developing a business.

b. Diversification and Company size affect the value of the company because diversification give economic value in the form of increased sales and profits in all types of businesses. Companies also indicated the size of the market on increasing sales and profits.

c. Diversification has effect the capital structure for diversification to many loan capitals.

d. Company size has no effect on the capital structure for prioritizing the use of internal capital, and transition asset that is not working or transformed to enable as long as they provide economic value.

e. No mediation capital structure to the effects of diversification and the value of the company because it does not add to the debt.

f. No mediation capital structure to influence and size of the company with a value of companies due to the addition of fixed assets, it is generally financed by borrowing.

g. The results support the static trade-off theory by Myers and Majluf (1984), Jensen and Meckling (1976). Due to the strengthening of the capital structure with a capital increase sourced from internal priority.

\section{SUGGESTION AND LIMITATION}

Limitation of research on some exogenous variables as functions of the financial management of manufacturing industries such as company size, and diversification to firm value through a capital structure to take the unit of analysis on several companies in the manufacturing industry which listing in the capital market.

It shows the different characteristic with some sectors of the capital market are not tested. Supervision study element from the elements although the owner raised the agency theory, did not even see their involvement or relationship between the manager and the owner at several companies in the manufacturing industry listing in the capital market that can provide the potential for an increase or decrease companies value.

This research contributes theoretically is:

\section{VII.CONTRIBUTION}

a. The company's value can be enhanced through diversification, sales growth, capital growth, by expanding market to absorb large capital, focused and deliberate on major products, do savings by apply the principle of cost saving, and joint cost, create a unique product that no value competitive advantage, use technology that is relevant and easy to administer, and then prioritizing the use of existing resources, and improve the quality of the resources that would diversify. Allocate assets not economical, efficient use of assets and relevant, and increase through a pattern of cooperation and co-financing, or did the bank guarantee if a requirement for additional capital.

b. The capital structure can be increased by increasing the capacity of production and sales, product diversification, and increased investment, sales, and improve the quality of earnings through cash sales. And seek the sale in cash so that the higher cash flow, improve supervision of production and sales, provide more benefits to the supplier and marketer, and employees

\section{REFERENCES}

[1]. Aaker, D.1980.Marketing Research: Private and Public Sector Decisions. New York: Wiley.

[2]. Akoto.RK, Vitor,DA and Angmor PL.2013. Working capital management and profitability: Evidence from Ghanaian listed manufacturing firms, Journal of Economics and International Finance. Vol. 59, pp. 373-379, December.Bevan dan Danbolt (2000),

[3]. Andrayani, Devi dan Surya, Sudirman. 2012. Pengaruh Pertumbuhan Penjualan, Ukuran Perusahaan Dan Assets Terhadap Struktur Modal.

[4]. Badan Pusat Statistik2013. Edisi Juli bps.go.id. [Online].http://sp2010.bps.go.id/index.php/site/tabel?tid=321

[5]. Baker, M. \& R. Wurgler. 2002. Market Timing and Capital Structure. Journal of Finance 57, pp. 1-32.

[6]. Bambang Riyanto. 2001. Dasar-Dasar Pembelanjaan Perusahaan. Edisi Keempat. Yogyakarta: BPFE

[7]. Berger, PG, \& Ofek, E. 1995. Diversification's effect on firm value. Journal ofFinancial Economics, 37 , 39-65.

[8]. Bevan, A. \& Danbolt, J. 2000. Dynamics in the Determinants of Capital Structure in the UK. Working Paper, University of Glasgow.

[9]. Booth, L, Aivazian, V., Demirguc-Kunt, A . and Maksimovi c , V. 2001. Capital Structure in developing Countries. The Journal of Finance, 56, 87- 130 .

[10]. Brigham Eugene F., Gapenski, Louis C. 1996, Intermediate Financial Management, $5^{\text {th }}$ Ed., The Dryden Press, Florida, United State. 
[11]. Brigham, Eugene F and Joel F. Houston. 2004. Fundamentals of FinancialManagement. Forth Edition, USA, South WesternThomson Learning.

[12]. Bunkaawanicha, P; Gufta, J \& Rokhim, R. 2003. Debt and Entrencheent: Evidence from Thailand and Indonesia. Social Science Network Electronic Paper Collection. http://ssrn/com/abstract.

[13]. Chan, L.K.C, Karceski, J. and Lakonishok, J. 1998. The Risk and Return from Factors. Journal of Financial andQuantitative Analysis. Vol.33 No.2.

[14]. Chen CJP, Cheng CSA, Jia H, Jawon K. 1997. An investigation of the relationship between international activities and capital structure. Journal of International Business Studies 28 : 563.

[15]. Chen, J., \& Strange, R. 2005. The Determinants of Capital Structure: Evidence from Chinese Listed Companies. Economic Change and Restructring, 38, 11-35. http://dx.doi.org/10.1007/s10644- 005-4521-7

[16]. Dewa Kadek Oka Kusumajaya.2011. Pengaruh Struktur Modal Dan Pertumbuhan Perusahaan Terhadap Profitabilitas Dan Nilai Perusahaan Pada Perusahaan Manufaktur Di Bursa Efek Indonesia.

[17]. Eka, Irawati2010. Pengaruh Struktur Modal, Pertumbuhan Laba, Ukuran Perusahaan Dan Likuiditas Terhadap Kualitas Laba. Jurnal Unnes. Vol 1, No 2 (2012).

[18]. Eli Safrida. 2008. Pengaruh Struktur Modal Dan Pertumbuhan Perusahaan Terhadap Nilai Perusahaan Pada Perusahaan Manufaktur Di Bursa Efek Jakarta. Tesis. Universitas Sumatera Utara. Medan.

[19]. Elsas, R., \& Florysiak, D. 2008. Empirical Capital Structure Research: New Ideas, Recent Evidence, and Methodological Issues. Discussion Paper at Munich School of Management, Munich, July 2008.

[20]. Ferdinand, A. 2006. Structural Equation Modeling dalam Penelitian Manajemen. Badan Penerbit Universitas Diponegoro, Semarang.

[21]. Gaud, Philippe, Martin Hoesli, Andre Bender. 2006. Debt-Equity Choice In Europe.International Review Of Financial Analysis. Article In Press.

[22]. Gaudi, P., Jani, E., Hoesli, M. dan Bender, Andre. 2003, "modalstruktur perusahaan Swiss: Sebuah analisis empiris menggunakan panel dinamis data "FAME,Research Paper $\mathrm{N}^{\circ} 68$

[23]. Harris, Milton, and Raviv,Artur . 1990, Capital structure and the informational role of debt, Journal of Finance 45, $321-349$.

[24]. Hitt MA, Tihanyi L, Miller T, Connelly B. 2006. International diversification: Antecedents, outcomes, and moderators. Journal of Management $32: 831-867$

[25]. Holz, Carsten A.2002. Dampak Rasio Kewajiban-Asset di Profitabilitas di China Milik Negara Industri Enterprises, China Economic Review, 13: 1-26.

[26]. Homaifar, Ghassem, Z, and Benkato, O,1994, "An Empirical Model of Capital Structure: Some New Evidence”, Journal of Business Finance \& Accounting, 21 (1), January1994

[27]. Imam Ghozali,2008,Structural Equation Modeling: Metode Alternatif denganPartial Least Square (PLS), Universitas Diponegoro, Semarang.

[28]. Jensen, M. and Meckling, W.1976.Theory of the Firm: Managerial Behaviour, Agency Costs and Ownership Structure.Journal of Financial Economics, Vol. 3, 1976, pp. 305-360.

[29]. Jensen, M.1986.Agency cost of Free Cash Flow, Corporate Finance and Takeovers", American Economic Review, Vol. 76, 1986, pp.323-339

[30]. Kemenperindag.17 Oktober 2016.http://www.kemenperin.go.id /artikel/8546/Industri-Manufaktur-Ekspansi-Rp-96,5-T

[31]. Kunthi Fahmar SandySelasa, 17 Mei 2016 - SindoNews.Com (http://ekbis.sindonews.com/read/1109283/33/utang-luar-negeri-rikuartal-i-2016-meningkat-5-7-1463486196)

[32]. La Rocca, M., La Rocca, T., Gerace, D. \& Smark, CJ 2009. Pengaruh diversifikasi terhadap struktur modal. Jurnal Akuntansi \& Keuangan, 49 4, 799-826.

[33]. Lang, LHP, \& Stulz, RM 1994. Tobin's q, corporate diversification, and firm performance. Journal of Political Economy, 102 , 12481280.

[34]. Li, Ming Fang dan Yim Yu Wong.2003.Diversification and Economic Performance: An Empirical Assessment Of Chinese Firms, Asian Pacific Journal Of Management, Vol 20.

[35]. Malhotra, Naresh K., 1999. Marketing Research: An Applied Orientation, ThirdEdition, Prentice Hall International Inc, New Jersey.

[36]. Mas'ud, M. 2008. Faktor-faktor penentu struktur Modal serta Dampaknya terhadap Nilai Perusahaan, Disertasi Program Doktor, Universitas Brawijaya, Malang. Tidak dipublika

[37]. Masnoon, M. dan Anwar, F. 2012, "Struktur modal Penentu KSE terdaftar Perusahaan farmasi ", GMJACS, Volume 2, Nomor 1, tersedia di:http://ssrn.com/abstract=2207630.

[38]. Michell Suharli.2006. Studi Empiris Terhadap Faktor-Faktor Yang Mempengaruhi Nilai Perusahaan Pada Perusahaan Go Public Di Indonesia, Jurnal Maksi Vol.6 No.1 Januari 2006

[39]. Miller,Danny.1983.The Correlates of Entrepreneurship in Three Types of Firms Management Science.Vol. 29, No. 7 Jul., 1983, pp. 770-791 Published by: Informs Stable URL: http://www.jstor.org/stable/2630968.

[40]. MirnaAmirya,Sari Atmini,2007. Faktor-Faktor Yang MempengaruhiNilai Perusahaan Yang Di MediasiOleh Leverage Perusahaan SebagaiVariabel Intervening; SebuahPerspektif Pecking Order Theory.JurnalThe $1^{\text {st }}$ Accounting Conference Fakulty Of Economics Universitas Indonesia

[41]. Modigliani, F., and Miller, M. H., 1958, The Cost of Capital, Corporation Finance and The Theory of Investment. The American Economic Review, Vol. XLVIII, No.3, pp. 261-297.

[42]. Moh'd, M. A., Perry, Rimbey, 1998, The Impact of Ownership Structure on Corporate Debt Policy: A Time Series Cross=Sectional Analysis, Financial Review, August, Vol. 33, pp. 85-99.

[43]. Myers, SC, \& Majluf, NS .1984. Corporate financing and investment decisions when firms have information that investors do not have. Journal of Financial Economics, 13, 187-221.

[44]. Onaolapo, AA, \& Kajola, SO .2010. Capital Structure and Firm Performance: Evidence from Nigeria. European Journal of Economics, Finance, and Administrative Sciences, 25, 70-82.

[45]. Oviatt, B.1984.On the Integration of Financial Management and Strategic Management.Academy of Management, Best Paper Proceedings, 1984, pp. 27-31.

[46]. Pandey, M. 2001. Capital Structure and the Firm Characteristics: Evidence from an Emerging Market. Working Paper, Indian Institute of Management Ahm.

[47]. Qureshi, M A, Akhtar, Waqas, dan Imdadullah, Muhammad.2012.Does Diversification Affect Capital Structure and Profitability in Pakistan?.Journal Of Asian Social Science Vol. 8, No. 4. Pp 30-42

[48]. Rachmawati, Andri dan Hanung Triatmoko. 2007. Analisis Faktor-Faktor yang Mempengaruhi Kualitas Laba dan Nilai Perusahaan. Dalam Simposium Nasional Akuntansi X, Makassar. 
[49]. Rajan, L. Zingales. 1995. What Do We Know About Capital Structure? Some Evidence from International Data, Journal of Finance, Vol.50, No.5, 1421-1460, 1995.

[50]. Ridha Yusra Oktaviola. 2012. Analisis pengaruh cash holding, leverage, dan tingkat pajak terhadap nilai perusahaan yang berkendala keuangan : studi pada perusahaan manufaktur di Bursa Efek Indonesia periode 2006-2011.

[51]. Ross, Stephen A., 1977, The determination of financial structure: the incentive- signalling approach, Bell Journal of Economics 8, 2340.

[52]. Sartono Agus, 1997. Manajemen Keuangan Edisi tiga, Badan Penerbit Fakultas Ekonomi, Yogyakarta.

[53]. Shin dan Stulz (2000.Firm Value, Risk, And Growth Opportunities. Penelitian yang dilakukannya membahas tentang perubahan risiko ekuitas perusahaan terhadap nilai perusahaan. Penelitiannya dimulai dengan perusahaan yang tercatat di COMPUSTAT periode 1965 sampai dengan tahun 1992.

[54]. Shubita, Mohammad Fawzi and Maroof Alsawalhah, Jaafer.2012.The Relationship between Capital Structure and Profitability.International Journal of Business and Social Science Vol. 3 No. 16 [Special Issue - August 2012]

[55]. Siallagan, Hamonangan Dan Mas'ud, Machfoedz. 2006.Mekanisme Corporate Governance, Kualitas Laba Dan NilaiPerusahaan. Simposium Nasional Akuntansi 9 Padang. Padang, 23-26 Agustus 2006

[56]. Singarimbun, Masri dan Sofian Effendi. 1989. Metode Penelitian Survai.Jakarta : LP3S

[57]. Singh, Manohar., Wallace N. Davidson, Jo-Ann Suchard. 2003. Strategi diversifikasi perusahaan dan struktur modal. The Quarterly Review Ekonomi dan Keuangan 432003 147-167. University of New South Wales, Sydney, NSW 2052, Australia

[58]. Smith, C.W., dan R.L. Watts, 1992, The Investment Opportunity Set and Corporate Financing, Dividend, and Compensation Policies, Journal of Financial Economics, Vol. 32: 263-292.

[59]. Solimun,2008,Understanding Quantitative Methods AdvancedStructural Equation Modeling and Partial Least Square. StatisticsStudies Program, State University of Brawijaya: Malang.

[60]. Song H. 2005, "Struktur Modal Penentu-An Studi EmpirisPerusahaan Swedia ", The Royal Institute of teknologi Centre of Excellence Ilmu Pengetahuan Sriwardany.2006.Pengaruh Pertumbuhan Perusahaan Terhadap Kebijakan Struktur Modal Dan Dampaknya Terhadap Perubahan Harga Saham Pada Perusahaan Manufaktur Tbk.

[61]. Stulz, R.M. 1990.Managerial Discreation and Optimal Financing Policies”.Journal Of Financial Economics. Vol.26, Hal: 3-27.

[62]. Sudarma, Made, 2004. Pengaruh Struktur Kepemilikan Saham, Faktor Intern dan Faktor Ekstern terhadap Struktur Modal dan Nilai Perusahaan. Ringkasan Disertasi. Program Pascasarjana. Universitas Brawijaya. Malang.

[63]. Sugiyono,2002,Metode Penelitian Bisnis, Cetakan ke empat,Alfabeta,Bandung.

[64]. Sunder, LS, \& Myers, SC 1999. Testing static tradeoff against pecking order models of capital structure. Journal of Financial Economics, 51, 219-244.

[65]. Titman dan Wessels., 1988. The Determinants of Capital Structure Choice, Journal of Finance, 43.

[66]. Um, T. 2001. Determination of Capital Structure and Prediction of Bankruptcy in Korea. Unpublished Ph.D Thesis. Ithaca: Cornell University.

[67]. Weston, J.F. dan T.E. Copeland. 1997. Manajemen Keuangan,Edisi Kesembilan, terjemahan Jaka Wasana dan Kibrandoko, Binarupa Kasara, Jakarta, Indonesia.

[68]. Wippern,R.1966.Financial Structure and The Value of The Firm, The Journal ofFinance ,214:615-633.

[69]. Zou, Hong And Jason Zezhong Xiao. 2006. The Financing Behaviour Of Listed ChineseFirms. The British Accounting Review, 38, pp.239-258. 